\title{
Avançando na construção de mais um periódico no campo científico da alimentação e nutrição a passos regulares e seguros
}

\section{Advancing in the construction of another journal in the scientific field of food and nutrition with regular and safe steps}

Durante a produção deste segundo número de DEMETRA: Alimentação, Nutrição छ Saúde, alguns acontecimentos nos trouxeram sentimentos de realização e de alegrias. A manutenção da periodicidade quadrimestral da revista é fato consolidado. O que no início caracterizou-se como um lance de confiança, hoje é estrada percorrida e caminho sem volta.

O aventar dessa possibilidade tem seus pilares assentados sobre a quantidade crescente de artigos submetidos para avaliação. Nos últimos quatro meses, recebemos um número substantivo de originais, suficiente para nos garantir material de publicação durante todo este ano corrente até o início de 2013.

Registremos que a qualidade das avaliações é crescente e, conforme nossos compromissos explicitados em editoriais anteriores, o tempo de avaliação dos originais vem sendo reduzido regularmente. Com isso, passamos a vivenciar o aumento do número de artigos publicados por fascículo, o que, temos certeza, vai se manter e se intensificar. Mais algum tempo em compasso de consolidação e passaremos a considerar, fortemente, a trimestralidade.

Enquanto a consolidação acontece, seguimos em nosso labor, preparando o periódico para suas primeiras indexações. Esperamos poder anunciar a inclusão de DEMETRA: Alimentação, Nutrição E Saúde em bases indexadoras ainda este ano ou, o mais tardar, na primeira metade de 2013.

Enquanto trabalhamos com firmeza no aprimoramento da revista, alegramo-nos ao receber originais de regiões mais continentais do País, um dos quais publicados neste número. Também ficamos muito honrados em poder contar com mais uma entrevista internacional em nossas páginas.

Nada disso seria possível sem o sólido apoio que recebemos da UERJ, através da Sub-Reitoria de Extensão, que nos propicia o SEER e o suporte técnico correspondente, da Sub-reitoria de Pósgraduação e Pesquisa, e da Adminsitração Central, que não medem esforços para nos proporcionar 
condições para a implementação deste projeto. A sustentação que nos propiciam o Instituto de Nutrição e o Programa de Pós-graduação em Alimentação, Nutriçao e Saúde correspondem a bases fortes que nos dão tranquilidade e segurança para prosseguir. Toda essa infraestrutura nos permitirá construir condições para pleitear recursos nas tradicionais agências de fomento à pesquisa, fazendo delas também coparticipantes do crescimento do campo científico da Alimentação e Nutrição, através de nosso periódico.

Destaque especial deve ser dado à equipe de produção da revista: qualidade, cuidado, responsabilidade e profissionalismo marcam sua atuação permanentemente. E a confiança em nós depositada pelos autores não pode deixar de ser registrada. Esperamos estar respondendo à altura de suas expectativas.

Por todos esses condicionantes favoráveis, consideramos que nos é razoável e pertinente pensar que estamos avançando na construção de mais um periódico no campo científico da Alimentação e Nutrição a passos regulares e seguros. Como sempre, caros leitores, sintam-se todos convocados a esse desafio: enviem-nos seus originais, suas cartas, suas considerações. Nós os teremos na mais alta conta!

Shirley Donizete Prado

Editora 